\title{
ANALISIS PENGARUH PERSEPSI RESIKO, PROMOSI, DAN KEPERCAYAAN MEREK TERHADAP NIAT BELI PASCA COVID-19
}

\author{
*Khilyatin Ikhsani ${ }^{1}$, Christina Catur Widayati ${ }^{2}$, Nur Endah Retno Wuryandari ${ }^{3}$ \\ ${ }^{1}$ Program Studi, Pajak Politeknik Keuangan Negara STAN, Tangerang Selatan, Indonesia \\ ${ }^{2}$ Fakultas Ekonomi dan Bisnis Universitas Mercu Buana, Jakarta, Indonesia \\ ${ }^{3}$ Fakultas Bisnis dan Ilmu Sosial, Universitas Dian Nusantara, Jakarta, Indonesia
}

*Email Korespondensi:

khilyatin.ikhsani@gmail.com

\section{ARTIKEL INFORMASI}

Diterima:

3 March 2021

Direvisi:

15 April 2021

Dipublikasi: 16 Mei 2021

\begin{abstract}
ABSTRAK
Di tahun 2020, Indonesia menghadapi Wabah Coronavirus Diseases (Covid-19). Sektor pariwisata merupakan salah satu sektor yang sangat terdampak akibat pandemi covid 19. Traveloka sebagai salah satu perusahaan startup unicorn yang bergerak dibidang akomodasi dan pariwisata juga ikut terdampak dari imbas peraturan pembatasan sosial berskala besar. Penelitian ini bertujuan untuk mengetahui pengaruh persepsi resiko terhadap niat beli, pengaruh promosi terhadap niat beli, dan pengaruh kepercayaan merek terhadap niat beli Traveloka Pasca Covid-19. Desain penelitian ini dengan eksplanatory. Teknik pengambilan sampel dalam penelitian ini dengan mengambil teori dari Hair lima kali indikator dan mengisi kuisioner yaitu menggunakan metode accidental sampling namun tetap memenuhi kriteria yang sudah ditentukan. Teknik samplingnya adalah Purposive Sampling dengan jumlah populasi masyarakat di Tangerang Kota. Metode analisis kuantitatif dengan alat bantu SMART PLS. Hasil dari penelitian ini adalah persepsi resiko berpengaruh positif dan signifikan terhadap niat beli, promosi berpengaruh positif dan signifikan terhadap niat beli, dan kepercayaan merek tiak berpengaruh terhadap niat beli.
\end{abstract}

Kata Kunci: Perceived Risk, Promotion, Brand Trust, Purchase Intention

\section{PENDAHULUAN}

Di tahun 2020, Indonesia menghadapi Wabah Coronavirus Diseases 2019 (Covid-19). Indonesia sudah dibuat kerepotan olehnya, berbagai sektor kehidupan manusia terkena dampaknya (Ajibulloh, 2020). Sektor pariwisata merupakan salah satu sektor yang sangat terdampak akibat pandemi covid 19. Hal ini dikarenakan kunci dari pengembangan sektor pariwisata adalah para wisatawan atau pengunjung yang datang. Jumlah wisatawan mancanegara menurun drastis seiring pengurangan penerbangan Internasional, wisatawan nusantara/domestik juga mengalami penurunan seiring dengan penerapan social and physical distancing. Adanya pandemi covid- 19 atau yang lebih dikenal dengan wabah virus corona ini memberi dampak yang signifikan secara global, termasuk memukul sektor pariwisata Indonesia (Nurhalimah, 2020). Pariwisata Indonesia juga terdampak, dengan Bali mengalami penurunan kedatangan wisatawan sebesar 33\% bila dibandingkan dengan Januari, dan penurunan tajam 96\% wisatawan Tiongkok. Hotel mengalami tingkat hunian yang sangat rendah, dengan beberapa hotel mencatat tingkat hunian 5\% dan bahkan $0 \%$ karena terlalu 
mengkhususkan diri pada pengunjung Tiongkok, adanya pembatasan perjalanan dari negara terinfeksi, dan ketakutan secara umum terhadap virus (Soetjipto, 2020).

Traveloka sebagai salah satu perusahaan startup unicorn yang bergerak dibidang akomodasi dan pariwisata juga ikut terdampak dari imbas peraturan pembatasan sosial berskala besar. Unicorn merupakan gelar yang diberikan pada suatu startup yang memiliki nilai valuasi (nilai dari suatu startup, bukan sekedar pendanaan yang diraih dari investor) lebih dari 1 miliar dolar AS (Shavira, 2020). Menanggapi situasi pelik ini, Traveloka berusaha untuk beradaptasi secara kreatif dengan memunculkan iklan terbarunya dengan mengusung kampanye bertahan dan melawan Covid-19 dengan judul Di Tahun Penuh Kata "Pertama", Traveloka \#JalanBersamaAnda. Kampanye ini menarik untuk diteliti karena iklan terbaru Traveloka yang dipublikasikan di media massa mendapat perhatian audiens dengan 24.999.381 kali ditonton di kanal Youtube Traveloka, 226.000 ditonton di Twitter dengan mendapat 365 Retweets dan 1.700 Likes. Di platform Instagram, Traveloka juga memposting iklan terbarunya dengan mendapat 1.068 .804 kali ditonton dan mendapat 867 komentar (Shavira, 2020).

Perkembangan iklan Traveloka sangat berkembang di segala lini media sosial menjadi menarik bagi peneliti untuk lebih lanjut mengkaji pengaruh promosi Traveloka. Pada iklan terbarunya, Traveloka mengajak untuk memerangi Covid-19 dengan berjauhan satu sama lain dan menunda rencana perjalanan (Shavira, 2020). Konsumen akan lebih mengingat produk dengan iklan yang menarik serta dapat memberikan informasi kepada konsumen. Ini disebut dengan daya tarik. Daya tarik yang timbul pada iklan akan menimbulkan respon pada konsumen. Pendekatan yang mengedepankan daya tarik iklan bertujuan untuk menarik perhatian konsumen untuk mengingat dan/atau mempengaruhi perasaan mereka mengenai produk. Traveloka dalam hal ini juga mengindikasikan memberikan daya tarik pada iklan terbarunya dengan membawa Covid-19 sebagai tema dalam kampanyenya (Shavira, 2020). Keadaan saat ini dicoba dikemas Traveloka secara menarik dengan cara menarik perhatian juga perasaan konsumen. Kedekatan personal tersebut digambarkan melalui dengan bagaimana Traveloka menyisipkan emosi, dan karakterikstik manusiawi lainnya pada kampanye tersebut (Shavira, 2020). Traveloka dikenal sebagai merek situs online booking tiket pesawat dan travel menjadi market leader pada Top Brand Index sejak tahun 2015-2020. Hal tersebut menandakan bahwa kepercayaan konsumen terhadap merek Traveloka sangat tinggi, karena nilai index brand tersebut jauh lebih tinggi dibandingkan dengan merek lainnya.

Tabel 1. Top Brand Index Fase 2 2020, Situs Online Booking Tiket Pesawat dan Travel

\begin{tabular}{cc} 
Brand & TBI 2020 \\
\hline Traveloka.com & $30.5 \%$ \\
\hline Tiket.com & $7,5 \%$ \\
\hline Trivago.co.id & $5,6 \%$ \\
\hline Agoda.com & $4,4 \%$ \\
\hline Pegipegi.com & $2,2 \%$ \\
\hline Swo
\end{tabular}

Sumber: Top Brand Awards, 2020

Dari data tersebut terlihat bahwa nilai TBI Traveloka.com sebesar 30.5\% menjadi market leader dari empat merek situs online booking tiket dan travel lainnya. TBI dari merek lainnya yaitu, Tiket.com sebesar 7.5\%, Trivago.com sebesar 5.6\%, Agoda.com sebesar 4.4.\%, dan pegipegi.com sebesar 2.2\%. Walaupun Traveloka menjadi pemimpin pasar di kategorinya, tidak menjadikan brand tersebut terbebas dari dampak pandemi Covid-19. Dari data Similarweb.com dapat dilihat bahwa traffic dari travel website mengalami penurunan drastis semenjak pandemi Covid-19. 


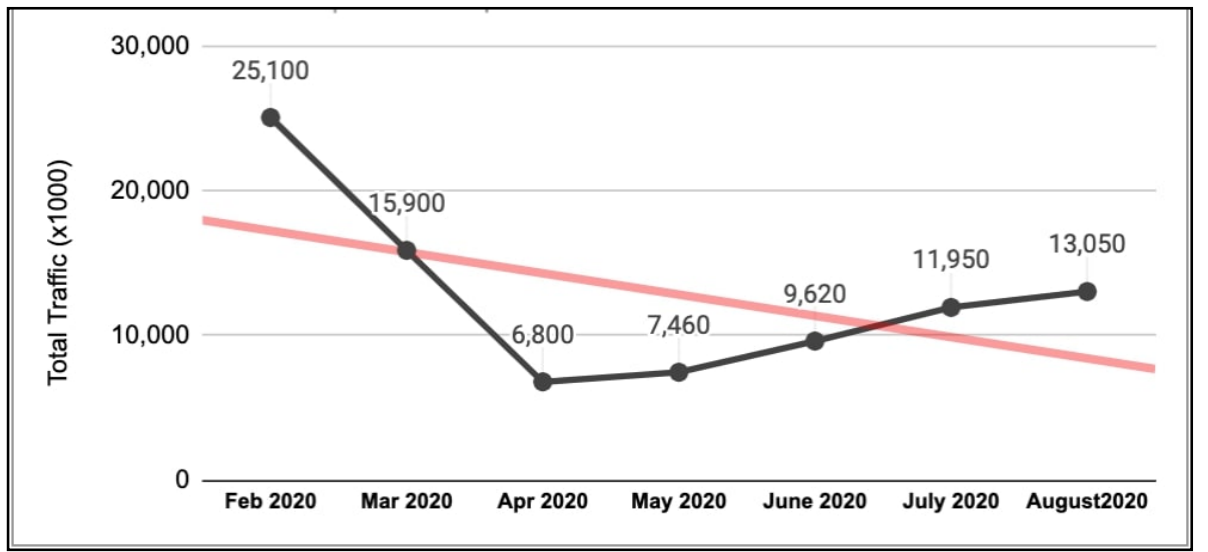

Gambar 1. Travel Websites Traffic

Sumber: Similarweb.com, 2020

Pandemi Covid-19 di Indonesia mengubah perilaku masyarakat Indonesia di dunia maya. Sejak April 2020, traffic situs-situs tersebut mulai mencatatkan pertumbuhan kunjungan, namun trennya masih menurun. Sejalan dengan menurunnya mobilitas masyarakat akibat pandemi Covid-19, situs-situs penyedia jasa penjualan tiket transportasi dan pemesanan hotel pun menurun. Jika dibandingkan dengan traffic pada bulan Februari 2020, traffic pada bulan Agustus 2020 telah berkurang pada kisaran 48\%. Seorang konsumen akan melakukan niat pembelian pada brand Traveloka jika persepsi resiko paska Covid-19 menurun, promosi yang dilakukan oleh Traveloka menarik dan meyakinkan paska Covid-19, juga kepercayaan merek Traveloka tinggi. Niat beli adalah kecenderungan dan hasrat yang secara kuat mendorong individu untuk membeli suatu produk. Sesuai dengan hasil dari beberapa penelitian dari Jordan et al. (2018), Pelaez et al. (2019), Yu et al. (2018), Putra et al. (2016), Bhatti \& Ur Rehman (2020), Milan et al. (2015), Nugroho (2020), Arum (2019), Muham et al. (2019), Navaneethakrishnan \& Sathish (2020), Putri \& Sudiksa (2018), Are \& Setyorini (2019), Putri \& Setyorini (2019), Tümer et al. (2019), dan Putra et al. (2016).

\section{KAJIAN PUSTAKA}

\section{Niat Beli}

Niat membeli sebagai niat konsumen dalam membeli produk, layanan atau merek tertentu. Niat membeli adalah dibentuk dengan asumsi transaksi tertunda dan, sebagai hasilnya, sering dianggap sebagai indikator penting aktual pembelian. Niat membeli juga telah dianggap sebagai prediktor akurat utama dalam pembelian aktual perilaku karena itu adalah tahap penting dari pembelian aktual yang dapat memberikan manfaat bagi perusahaan (Zahratu \& Hurriyati, 2020). Purchase intention akan timbul karena beberapa proses yang terjadi di pikiran para konsumen, yang sebenarnya merupakan proses yang dipengaruhi oleh faktor-faktor yang cukup sensitif, tergantung dari kebutuhan konsumen. Oleh sebab itu, minat beli merupakan proses yang kompleks dan rumit dimana banyak terjadi pertimbangan yang merupakan langkah awal konsumen dalam menkonsumsi suatu produk (Faresha, 2020).

Niat membeli sebagai "probabilitas bahwa pelanggan akan membeli produk." Kemungkinan datang ketika pelanggan memiliki motivasi yang mendorong mereka untuk mengambil tindakan. Ketika pelanggan memiliki motivasi yang kuat, mereka akan melakukannya didorong untuk memiliki produk atau layanan. Sebaliknya, memiliki motivasi yang lemah, mereka cenderung melakukannya hindari membeli produk atau layanan (Tarigan \& Jacqueline, 2018). Dimensi pada variabel niat beli yang digunakan pada penelitian ini berdasarkan kajian teori (Faresha, 2020) adalah :

a) Niat membeli,

b) Rekomendasi merek,

c) Keinginan untuk membeli ulang.

\section{Persepsi Resiko}

Persepsi resiko dinilai sebagai anggapan atau pendapat konsumen terhadap hasil negatif yang mungkin terjadi ketika melakukan transaksi secara online (Kusumawati et al., 2020). Persepsi resiko dapat diartikan sebagai resiko secara umum yang diterima oleh seseorang pada saat menggunakan suatu sistem (Dewi \& 
Warmika, 2016). Pengertian Persepsi resiko telah berubah sejak transaksi online populer. Di masa lalu, Persepsi resiko utamanya dianggap sebagai penipuan dan kualitas produk. Sekarang Persepsi resiko mengacu pada tipe tertentu dari keuangan, kinerja produk, sosial, psikologis, fisik dan risiko waktu ketika konsumen melakukan transaksi online. Menurut Kim, Persepsi resiko diartikan sebagai keyakinan konsumen tentang potensi hasil negatif yang tidak pasti dari transaksi online (Loanata \& Tileng, 2016).

Persepsi risiko ialah dimana ketika hendak membeli konsumen akan mempertimbangkan resiko yang akan terjadi. Risiko yang dipersepsikan ini akan didasarkan pada banyak pertimbangan yang bersumber dari informasi dan pengalaman terkait. Persepsi resiko yang dipersepsikan di definisikan sebagai ketidakpastian yang dihadapi konsumen ketika mereka tidak mampu melihat kemungkinan yang akan terjadi dari keputusan pembelian yang dilakukan (Istiqomah et al., 2019). Faktor utama yang mempengaruhi niat beli seseorang produk wisata basis online di masa pandemi (Kusumawati et al., 2020), yaitu:
a) Resiko keuangan
b) Resiko Produk
c) Resiko Informasi

\section{Promosi}

Promosi adalah suatu komunikasi informasi antara penjual dan pembeli yang bertujuan untuk mengubah sikap dan tingkah laku pembeli, yang tadinya tidak mengenal menjadi mengenal sehingga menjadi membeli dan tetap mengingat produk tersebut (Apri Khaerani \& Endang Prihatini, 2015). Promosi dilakukan untuk mengkomunikasikan informasi tentang produk mereka dan mempengaruhi konsumen untuk membelinya (Islamiyah, 2017). promosi adalah mengiklankan suatu produk atau merek, menghasilkan penjualan, dan menciptakan loyalitas merek atau brand (Zulfikar, 2016). Promosi mengacu pada alat promosi penjualan yang memiliki ciri-ciri tersendiri diantaranya sebagai berikut : (Kotler and Keller, 2013)
1) Komunikasi
2) Insentif
3) Undangan

\section{Kepercayaan Merek}

Kepercayaan merek adalah kemampuan merek untuk dipercaya, yang bersumber pada keyakinan konsumen bahwa produk tersebut mampu memenuhi nilai yang dijanjikan dan intensi baik merek yang didasarkan pada keyakinan konsumen bahwa merek tersebut mampu mengutamakan kepentingan konsumen (Rusmanida, 2020). Kepercayaan dalam suatu merek sebagai suatu keinginan konsumen untuk mempercayakan pada merek dan dihadapkan pada resiko, karena mempunyai harapan bahwa merek akan menyebabkan hasil yang positif. Keinginan tersebut berakar dari pemahaman terhadap pihak lain yang didasarkan pada pengalaman (Masitoh et al., 2019). Kepercayaan yang dimaksud dalam konteks e-commerce mencakup kepercayaan konsumen online dan harapan dari karakteristik penjual online terhadap merek (Ayu \& Sulistyawati, 2018). Dimensi kepercayaan merek adalah sebagai berikut:
1) Achieving result
2) Acting with integrity
3) Demonstrate concern

\section{METODE}

Metode analisis penelitian ini adalah metode kuantitatif dan alat analisisnya dengan SMART PLS. Uji instrumen (angket) terlebih dahulu diuji dengan validitas dan reliabilitas serta uji Hipotesis dengan alpha 5 persen $(0,05)$. Persepsi resiko, promosi, dan kepercayaan merek sebagai variabel independen, niat beli sebagai variabel dependen. Penelitian ini dilakukan dengan menggunakan metode deskriptif dan melalui pendekatan kuantitatif. Penelitian deskriptif bertujuan untuk menggambarkan karakteristik kelompok tertentu. Analisis kuantitatif dipilih karena dalam penelitian ini bertujuan untuk mengetahui hubungan antara variabel-variabel ini, nilai-nilai yang dinyatakan dalam bentuk numerik atau lebih menekankan pada data dalam bentuk angka yang diproses secara matematis dengan rumus statistik (Sugiyono, 2013). Metode penelitian kuantitatif dapat diartikan sebagai metode penelitian berdasarkan filosofi positivisme, digunakan untuk meneliti populasi dan sampel tertentu, teknik pengambilan sampel umumnya dilakukan secara acak, pengumpulan data menggunakan instrumen penelitian, Analisis data adalah kuantitatif / statistik untuk menguji hipotesis yang ditetapkan (Sugiyono, 2013). 
Populasi merupakan keseluruhan elemen yang hendak diduga karakteristiknya, sedangkan sampel merupakan bagian dari populasi yang hendak diuji karakteristiknya (Suliyanto, 2018). Populasi dalam penelitian ini adalah konsumen Traveloka di wilayah kota Tangerang. Ukuran sampel harus 100 atau lebih besar. Sebagai aturan umum, jumlah sampel minimum setidaknya lima kali lebih banyak dari jumlah item pertanyaan yang akan di analisis Sampel penelitian yang diperoleh berjumlah 100 responden (Hair et al, 2016). Penarikan sampel dengan teknik Nonprobability Sampling yaitu teknik pengambilan sampel yang tidak memberi peluang atau kesempatan sama bagi setiap unsur atau anggota populasi untuk dipilih menjadi sampel dengan purposive sampling yaitu dengan pemilihan responden yang berusia 17 tahun ke atas, sudah bekerja, dan yang berniat melakukan wisata pada saat setelah masa pandemi covid-19. Pengumpulan data dilakukan dengan menggunakan teknik kuesioner, di mana responden menjawab pertanyaan yang telah disusun dalam bentuk pilihan dan skala pertanyaan menggunakan skala Likert (1-5). Metode analisis data dalam penelitian ini adalah regresi dengan bantuan perangkat lunak SMART PLS.

\section{HASIL DAN PEMBAHASAN}

\section{Hasil}

Hasil penelitian ini sudah melewati proses validitas dan realibitas. Skor loading semua indikator niat beli semuanya berada di angka $>0,5$. Dari hasil output SmartPLS semua konstruk memiliki nilai composite reliability di atas 0,70 . Jadi dapat disimpulkan bahwa konstruk memiliki reliabilitas yang baik. Adapun model pengukuran untuk uji validitas dan reabilitas, koefisien determinasi model dan koefisien jalur untuk model persamaan, dapat dilihat pada gambar berikut:

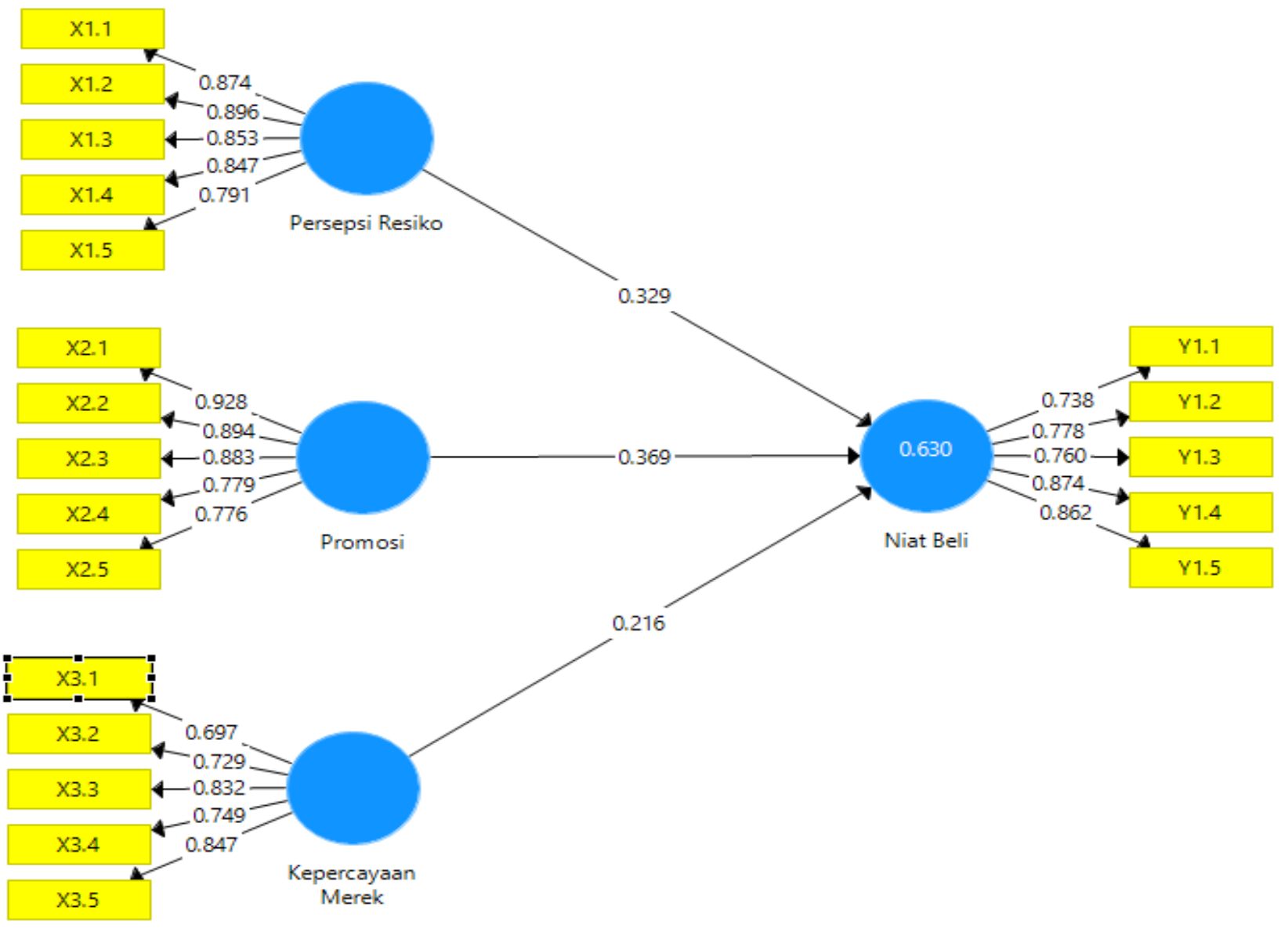

Gambar 2. Hasil PLS Algorithm

Sumber: Data primer, diolah 2021

Tabel 2. Pengujian Hipotesis

\begin{tabular}{lllll}
\hline Hipotesis & Pengaruh & t-Hitung & $P$ - & Hasil \\
\hline
\end{tabular}




\begin{tabular}{clccc}
\hline & & \multicolumn{3}{c}{ Value } \\
\hline H1 & $\begin{array}{l}\text { Persepsi Resiko Berpengaruh } \\
\text { terhadap Niat Beli }\end{array}$ & 2,700 & 0.007 & Terbukti \\
H2 & $\begin{array}{l}\text { Promosi Berpengaruh terhadap } \\
\text { Niat Beli }\end{array}$ & & & Terbukti \\
H3 & $\begin{array}{l}\text { Kepercayaan merek Berpengaruh } \\
\text { terhadap Niat Beli }\end{array}$ & 1,770 & 0.001 & Ditolak \\
\hline
\end{tabular}

Sumber: Data primer, diolah 2021

Tabel di atas memberikan pembuktian hipotesis penelitian atas pengaruh yang diberikan terhadap Persepsi Resiko, Promosi, dan Kepercayaan merek terhadap Niat Beli:

a) Hipotesis pertama yang menyatakan bahwa Persepsi Resiko Berpengaruh terhadap Niat Beli terbukti kebenarannya. Hal ini dapat dilihat dari nilai $\mathrm{t}$ statistik sebesar 2,700 yang lebih besar dari nilai $\mathrm{t}$ tabel $=1,96$, serta nilai probabilitas sebesar 0,007 yang lebih kecil dari batasan nilai kritis yang ditentukan yakni 0,05. Dengan demikian dinyatakan bahwa Persepsi Resiko berpengaruh dan signifikan terhadap Niat Beli.

b) Hipotesis kedua yang menyatakan bahwa Promosi Berpengaruh terhadap Niat Beli dapat terbukti kebenarannya. Hal ini dapat dilihat dari nilai t statistik sebesar 3.431 yang lebih besar dari nilai $t$ tabel $=1,96$, serta nilai probabilitas sebesar 0,001 yang lebih kecil dari batasan nilai kritis yang ditentukan yakni 0,05. Dengan demikian dinyatakan bahwa Promosi berpengaruh signifikan terhadap Niat Beli.

c) Hipotesis Ketiga yang menyatakan bahwa kepercayaan merek Berpengaruh terhadap Niat Beli ditolak. Hal ini dapat dilihat dari nilai $t$ statistik sebesar 1,770 yang lebih kecil dari nilai $t$ tabel $=1,96$, serta nilai probabilitas sebesar 0,076 yang lebih besar dari batasan nilai kritis yang ditentukan yakni 0,05 . Dengan demikian dinyatakan bahwa kepercayaan merek berpengaruh dan signifikan terhadap Niat Beli.

\section{Pembahasan \\ Pengaruh variabel Persepsi Resiko terhadap Niat Beli}

Berdasarkan tabel 5.10. di atas variabel persepsi resiko (X1) berpengaruh positif dan signifikan terhadap variabel niat beli (Y). Hal ini menunjukkan bahwa adanya persepsi resiko yang dirasakan oleh calon konsumen terhadap niat beli dengan aplikasi Traveloka . Skor loading yang paling rendah adalah sebesar 0,791 yaitu pada peryataan persepsi resiko yang berbunyi "Saya merasa terlalu banyak ketidakpastian seandainya memberikan informasi pribadi pada Traveloka". Konsumen masih menganggap tidak ada ketidakpastian jika memberikan informasi ke Traveloka. Sementara skor loading yang paling tinggi terdapat pada pernyataan sebesar 0,896 yang berbunyi "Menurut saya, bertransaksi menggunakan aplikasi Traveloka dapat mengalami kerugian secara keuangan". Hasil ini dapat dijelaskan bahwa konsumen merasakan persepsi resiko secara keuangan yang dapat mempengaruhi niat beli dengan aplikasi Traveloka.

Skor loading tertinggi pada variabel niat beli adalah indikator Y1.4 sebesar 0,874 yang berbunyi "Saya akan mereferensikan manfaat Traveloka kepada orang lain yang akan berniat membeli produk". Hal ini menandakan bahwa konsumen mengetahui merek dari Traveloka dapat direkomendasikan ke lainnya. Sedangkan indikator yang memiliki skor loading terendah adalah indikator Y1.1 sebesar 0,727 yang berbunyi "Saya niat menggunakan aplikasi Traveloka untuk kebutuhan saya". Dengan demikian, dapat dijelaskan bahwa konsumen berniat menggunakan aplikasi Traveloka tidak untuk dirinya. Hal tersebut didukung dengan penelitian terdahulu diantaranya: Jordan et al. (2018), Pelaez et al. (2019), Yu et al. (2018), Putra et al. (2016), Bhatti \& Ur Rehman (2020), Milan et al. (2015), bahwa persepsi resiko berpengaruh postif dan signifikan terhadap niat beli.

\section{Pengaruh variabel promosi terhadap niat beli}

Berdasarkan tabel 5.10. diatas variable promosi (X2) berpengaruh positif dan signifikan terhadap variabel niat beli (Y). Hal ini menunjukkan bahwa promosi dari Traveloka dapt mempengaruhi niat beli konsumen paska covid-19 untuk berwisata atau berpergian. Skor loading yang paling tinggi ditemukan pada indikator yang berbunyi "Traveloka senantiasa memberikan informasi program promosi dalam jaringan media sosial nya" dengan skor loading sebesar 0,928 . Hal ini menandakan bahwa Traveloka sudah melakukan promosi dengan mengkomunikasikan promosi mereka menggunakan media sosial. Sementara itu, skor loading terendah ditemukan pada indikator yang berbunyi "Traveloka memperkenalkan produk atau jasa yang baru diluncurkan 
dalam bentuk undangan pelatihan secara gratis" dengan skor loading sebesar 0,776 . Hasil ini menunjukkan bahwa Traveloka .

Skor loading tertinggi pada variabel niat beli adalah indikator Y1.4 sebesar 0,874 yang berbunyi "Saya akan mereferensikan manfaat Traveloka kepada orang lain yang akan berniat membeli produk". Hal ini menandakan bahwa konsumen mengetahui merek dari Traveloka dapat direkomendasikan ke lainnya. Sedangkan indikator yang memiliki skor loading terendah adalah indikator Y1.1 sebesar 0,727 yang berbunyi "Saya niat menggunakan aplikasi Traveloka untuk kebutuhan saya". Dengan demikian, dapat dijelaskan bahwa konsumen berniat menggunakan aplikasi Traveloka tidak untuk dirinya. Hal tersebut didukung dengan penelitian terdahulu diantaranya: Nugroho (2020), Arum (2019), Muham et al. (2019), bahwa promosi berpengaruh postif dan signifikan terhadap niat beli.

\section{Pengaruh variabel kepercayaan merek terhadap niat beli}

Berdasarkan tabel 5.10. diatas variabel kepercayaan merek (X3) tidak berpengaruh terhadap variabel niat beli (Y). Hal ini menunjukkan bahwa kepercayaan merek dari aplikasi Traveloka tidak mempengaruhi niat beli konsumen untuk berwisata atau berpergian menggunakan aplikasi Traveloka paska covid 19. Skor loading yang paling rendah adalah sebesar 0,854 yaitu pada peryataan harga yang berbunyi "Saya percaya bahwa Traveloka akan memberikan kepuasan dalam bertransaksi". Konsumen masih menganggap bahwa Traveloka kurang mampu memberikan kepuasan pelanggan dalam bertransaksi menggunakan aplikasi Traveloka. Sementara skor loading yang paling tinggi terdapat pada pernyataan sebesar 0,944 yang berbunyi "Saya percaya bahwa Traveloka memenuhi tanggung jawabnya terhadap pelanggan". Hasil ini dapat dijelaskan bahwa konsumen percaya Traveloka dapat bertanggung jawab atas keluh kesah atau kerugian yang dialami oleh konsumen.

Skor loading tertinggi pada variabel niat beli adalah indikator Y1.4 sebesar 0,874 yang berbunyi "Saya akan mereferensikan manfaat Traveloka kepada orang lain yang akan berniat membeli produk". Hal ini menandakan bahwa konsumen mengetahui merek dari Traveloka dapat direkomendasikan ke lainnya. Sedangkan indikator yang memiliki skor loading terendah adalah indikator Y1.1 sebesar 0,727 yang berbunyi "Saya niat menggunakan aplikasi Traveloka untuk kebutuhan saya". Dengan demikian, dapat dijelaskan bahwa konsumen berniat menggunakan aplikasi Traveloka tidak untuk dirinya. Hal tersebut didukung dengan penelitian terdahulu diantaranya: Navaneethakrishnan \& Sathish (2020), Putri \& Sudiksa (2018), Are \& Setyorini (2019), Putri \& Setyorini (2019), Tümer et al. (2019), Putra et al. (2016), bahwa kepercayaan merek berpengaruh negatif terhadap niat beli.

\section{KESIMPLAN DAN SARAN}

\section{Kesimpulan}

Berdasarkan hasil pembahasan pada bab sebelumya, maka dapat disimpulkan sebagai berikut:

1) Persepsi resiko berpengaruh positif dan signifikan terhadap niat beli. Persepsi resiko mengacu pada tipe tertentu dari keuangan, kinerja produk, sosial, psikologis, fisik dan risiko waktu ketika konsumen melakukan transaksi online. Semakin tinggi persepsi resiko yang dirasakan konsumen maka semakin rendah niat beli konsumen. Dan sebaliknya, semakin rendah persepsi resiko yang dirasakan konsumen maka semakin tinggi niat beli konsumen untuk melakukan transaksi menggunakan Traveloka.

2) Promosi berpengaruh positif dan signifikan terhadap niat beli. Promosi merupakan suatu komunikasi informasi antara penjual dan pembeli yang bertujuan untuk mengubah sikap dan tingkah laku pembeli, yang tadinya tidak mengenal menjadi mengenal sehingga menjadi membeli dan tetap mengingat produk tersebut. Semakin efektif promosi yang dilakukan oleh Traveloka maka semakin tinggi niat beli konsumen dalam bertransaksi menggunakan Traveloka.

3) Kepercayaan merek tidak berpengaruh terhadap niat beli. Kepercayaan dalam suatu merek sebagai suatu keinginan konsumen untuk mempercayakan pada merek dan dihadapkan pada resiko, karena mempunyai harapan bahwa merek akan menyebabkan hasil yang positif. Keinginan tersebut berakar dari pemahaman terhadap pihak lain yang didasarkan pada pengalaman. Dalam penelitian ini, niat beli konsumen dalam bertransaksi menggunakan Traveloka tidak berdasarkan dengan kepercayaan merek, tetapi pengaruh dari variabel lainya.

\section{Saran}

Beberapa hal yang disarankan oleh peneliti berdasarkan hasil penelitian adalah: 
1) Bagi Traveloka

a) Konsumen masih merasakan persepsi resiko secara keuangan yang dapat mempengaruhi niat beli dengan aplikasi Traveloka. Traveloka harus menjamin keamanan dalam hal keuangan saat konsumen bertransaksi menggunakan Traveloka. Untuk mengurangi persepsi resiko konsumen dalam bertransaksi menggunakan aplikasi Traveloka disarankan memperhatikan beberapa hal berikut, diantaranya ; a) Meningkatkan sistem keamanan pada aplikasi Traveloka dalam hal transaksi secara keuangan bagi konsumen terhadap mitra-mitra yang memberikan kerugian bagi konsumen; b) Memperhatikan dan mengevaluasi resiko produk dari mitra-mitra yang menawarkan produk kepada konsumen. Traveloka harus lebih selektif dalam menawarkan produk kepada konsumen; c) Meningkatkan sistem kemanan privasi data konsumen dari penyebarluasan data pribadi untuk hal yang disalahgunakan bagi pihak internal atau eksternal.

b) Konsumen merasa promosi Traveloka sudah efektif dalam mengkomunikasikan promosi untuk meningkatkan niat beli konsumen dalam bertransaksi menggunakan Traveloka. Untuk meningkatkan promosi aplikasi Traveloka disarankan memperhatikan beberapa hal berikut, diantaranya ; a) Meningkatkan komunikasi dengan konsumen dalam mempromosikan Traveloka; b) Meningkatkan insentif penawarkan kepada konsumen yang dapat menguntungkan bagi kedua belah pihak; c) Melakukan undangan berupa pe;atihan bagi mitra atau konsumen terhadap fitur-fitur baru yang ditawarkan oleh Traveloka.

2) Selain itu, peneliti selanjutnya harus dapat mengembangkan kembali variabel dan indikator yang belum digunakan dalam penelitian ini, seperti variabel e-wom, harga, brand awareness, dan sebagainya.

\section{REFERENCES}

Ajibulloh, A. A. (2020). Pemanfaatan Microsoft Powerpoint Sebagai Solusi Strategi Visual Digital Marketing Untuk Umkm Di Masa Pandemi. 4(1), 474-478.

Apri Khaerani, R., \& Endang Prihatini, A. (2015). Pengaruh Promosi dan Brand Image Terhadap Keputusan Pembelian Pada Layanan Traveloka. Jurnal Administrasi Bisnis, IX(III), 310-317.

Arum, W. S. (2019). Pengaruh promosi penjualan dan celebrity endorser terhadap niat beli produk tony moly delight tint (studi pada pengunjung royal plaza surabaya). 7(2), 393-399. http://jurnalmahasiswa.unesa.ac.id/index.php/jim/article/download/26336/24116

Ayu, D. P., \& Sulistyawati, E. (2018). Persepsi Nilai Pelanggan Memediasi Pengaruh Kepercayaan Merek Dan Kualitas Layanan Terhadap Loyalitas Pelanggan Berbelanja Online (Studi Kasus Pada Zalora Online $\begin{array}{llll}\text { Shop). E-Jurnal Manajemen Universitas Udayana, } & \text { 7(5), }\end{array}$ https://doi.org/10.24843/ejmunud.2018.v07.i05.p02

Bhatti, A., \& Ur Rehman, S. (2020). Perceived Benefits and Perceived Risks Effect on Online Shopping Behavior With the Mediating Role of Consumer Purchase Intention in Pakistan. International Journal of Management Studies, 26(1), 33-54. https://doi.org/10.32890/ijms.26.1.2019.10512

Dewi, N., \& Warmika, I. (2016). Peran Persepsi Kemudahan Penggunaan, Persepsi Manfaat Dan Persepsi Resiko Terhadap Niat Menggunakan Mobile Commerce Di Kota Denpasar. None, 5(4), 251442.

Faresha, K. S. (2020). Pengaruh Electronic Word of Mouth terhadap Purchase Intention yang dimediasi oleh Variabel Brand Image pada Situs Travel Online Traveloka (Studi pada Pengguna di Kota Malang). Jurnal Pemasaran, 2(4), 1-10.

Hair et al. (2016). A primer on partial least squares structural equation modeling (PLS-SEM). Sage publications.

Islamiyah, N. N. hidayati. (2017). Pengaruh Kualitas Pelayanan, Promosi, Dan Kepercayaan Terhadap Minat Beli Ulang (Studi Kasus pada pengguna E-commerce Shopee Mahasiswa Universitas Islam Malang) Oleh: Jurnal Riset Manajemen, $\quad 5(1), \quad 1-8$. https://ejournal.poltektegal.ac.id/index.php/siklus/article/view/298\%0Ahttp://repositorio.unan.edu.ni/2986 /1/5624.pdf\%0Ahttp://dx.doi.org/10.1016/j.jana.2015.10.005\%0Ahttp://www.biomedcentral.com/14712458/12/58\%0Ahttp://ovidsp.ovid.com/ovidweb.cgi?T=JS\&P

Istiqomah, Hidayat, Z., \& Jariah, A. (2019). Analisis Pengaruh Kepercayaan , Iklan dan Persepsi Resiko Terhadap Keputusan Pembelian di situs Shopee di Kota Lumajang. Jurnal Progress Conference, 2(July), 557-563.

Jordan, G., Leskovar, R., \& Marič, M. (2018). Impact of Fear of Identity Theft and Perceived Risk on Online Purchase Intention. Organizacija, 51(2), 146-155. https://doi.org/10.2478/orga-2018-0007 
Kotler and Keller. (2013). Manajemen Pemasaran (Second). Erlangga.

Kusumawati, I., Hartono, S., \& Kustiyah, E. (2020). Kemudahan, Kepercayaan Dan Persepsi Resiko Terhadap Keputusan Pembelian Pengguna Dompet Digital Ovo Di Surakarta. Journal of Management: Small and Medium Enterprises (SMEs), 11(1), 19-29. https://doi.org/10.35508/jom.v11i1.2315

Loanata, T., \& Tileng, K. G. (2016). Pengaruh Trust dan Perceived Risk pada Intention To Use Menggunakan Technology Acceptance Model (Studi Kasus Pada Situs E-Commerce Traveloka). Juisi, 2(1), 1-10. https://journal.uc.ac.id/index.php/JUISI/article/view/117/110

Masitoh, M. R., Wibowo, H. A., \& Ikhsan, K. (2019). Pengaruh Kualitas Pelayanan, Kepuasan Pelanggan , dan Kepercayaan Merek Terhadap Loyalitas Pelanggan Pada Pengguna Aplikasi Mobile Shopee. Jurnal Sains Manajemen, 5(1), 101-119.

Milan, G. S., Bebber, S., Toni, D. De, \& Eberle, L. (2015). Information Quality, Distrust and Perceived Risk as Antecedents of Purchase Intention in the Online Purchase Context. Journal of Management Information System \& E-Commerce, 2(2), 111-129. https://doi.org/10.15640/jmise.v2n2a2

Muham, E. D., Sidauruk, C., Irianto, B. P., Studi, P., Informasi, S., Industri, F. T., Atma, U., \& Yogyakarta, J. (2019). Proceeding SINTAK 2019 ISBN : 978-602-8557-20-7 Proceeding SINTAK 2019 ISBN : 978-6028557-20-7. 486-493.

Navaneethakrishnan, K., \& Sathish, A. S. (2020). It's all about brand love- expressing through purchase intention, brand trust and brand attitude. Journal of Critical Reviews, 7(4), 314-318. https://doi.org/10.31838/jcr.07.04.58

Nugroho, D. A. (2020). Pengaruh promosi penjualan dan celebrity endorser terhadap niat beli fashion brand lokal giyomi pada generasi y dan z. Jurnal Ilmu Manajemen Volume, 8(4).

Nurhalimah. (2020). Analisis dampak perkembangan pariwisata pulau santen banyuwangi pasca pandemi. $6(2), 361-369$.

Pelaez, A., Chen, C. W., \& Chen, Y. X. (2019). Effects of Perceived Risk on Intention to Purchase: A MetaAnalysis. Journal of Computer Information Systems, 59(1), 73-84. https://doi.org/10.1080/08874417.2017.1300514

Putra, I. P. A. P. A., Sukaatmadja, I. P. G., \& Giantari, I. G. A. . (2016). Pengaruh Persepsi Kemudahan Penggunaan, Persepsi Risiko, Terhadap Kepercayaan dan Niat Beli E-Ticket pada Situs Traveloka. EJurnal Ekonomi Dan Bisnis Universitas Udayana 5.9, 9, 3007-3030.

Putri, A. K., \& Setyorini, R. (2019). Pengaruh Electronic Word Of Mount dan Kepercayaan Konsumen Terhadap Niat Beli Produk di Shoppe Indonesia. Dinamika Ekonomi: Jurnal Ekonomi Dan Bisnis, 12(2), 216-230.

Putri, C. I. D., \& Sudiksa, I. B. (2018). Peran Kepercayaan Dalam Memediasi Pengaruh Persepsi Risiko Terhadap Niat Beli Online Pada Situs Lazada. E-Jurnal Manajemen Universitas Udayana, 7(7), 254165. https://doi.org/10.24843/EJMUNUD.2018.v07.i07.p04

Rusmanida. (2020). Pengaruh Kesadaran Merek Dan Persepsi Kualitas Terhadap Keputusan Membeli Secara Online Melalui Kepercayaan Merek Pada E-Commerce Shopee Di Kota Banjarmasin. JIMMU Jurnal Ilmu Manajemen, 5(1), 16-22.

Shavira, P. A. (2020). Jurnal Ilmu Komunikasi Antropomorfisme Brand: Kampanye Digital Pencegahan Covid-19 Oleh Traveloka Pendahuluan Novel coronavirus telah memberikan dampak besar kepada dunia . Virus yang saat ini menjadi pandemi mengakibatkan perubahan pada banyak sektor di. 10(2).

Soetjipto, N. (2020). Ketahanan UMKM Jawa Timur Melintasi Pandemi COVID-19.

Sugiyono. (2013). Statistika Untuk Penelitian. Alfabeta.

Suliyanto. (2018). Metode Penelitian Bisnis. Andi Offset.

Tarigan, R. S., \& Jacqueline. (2018). Millennials' Purchase Intention Towards Online Travel Agent in Indonesia. Petra International Journal of Business Studies, 1(1), 23-34. https://doi.org/10.9744/ijbs.1.1.23

Tümer, M., Aghaei, I., Nasser Eddine, Y., \& Öney, E. (2019). The impact of traditional and social media marketing on customers' brand trust and purchase intentions in the Turkish airline market. Journal of Research in Emerging Markets, 1(4), 55-68. https://doi.org/10.30585/jrems.v1i4.344

Yu, S., Hudders, L., \& Cauberghe, V. (2018). Selling luxury products online: The effect of a quality label on risk perception, purchase intention and attitude toward the brand. Journal of Electronic Commerce Research, 19(1), 16-35.

Zahratu, S. ., \& Hurriyati, R. (2020). Electronic Word of Mouth and Purchase Intention on Traveloka. 117(Gcbme 2018), 33-36. https://doi.org/10.2991/aebmr.k.200131.008

Zulfikar, R. S. E. P. F. B. A. J. T. A. F. (2016). Peningkatan Kesejahteraan Usaha Kecil Menengah (Ukm) 
JBEMK | Volume 1, Issue 1 (2021) | 81-90

Melalui E-Commerce Dan Promosi Jejaring Sosial Media (Studi Kasus: Kelurahan Gunung Sindur Kabupaten Bogor). JAMAIKA, 1(1), 83-96. 